\title{
Research Paper Economic analysis of production and export performance of litchi in Muzaffarpur district of Bihar
}

See end of the paper for authors' affiliations

Correspondence to :

Janmejay Kumar

Department of Agricultural

Economics, Sam

Higginbottom University

of Agriculture Technology

and Sciences, Allahabad

(U.P.) India

Email : janmejaykumarrau

@ gmail.com

Paper History :

Received : 26.05.2018;

Revised : 10.07.2018,

Accepted : 12.07.2018
ABSTRACT : This study in aimed at economic analysis of production and export performance of litchi in Muzaffarpur district of Bihar with specific objectives of determining the production and export trend and estimating the cost of production and farm profitability of litchi in the study area. A total of eight villages in the two sampled block viz., Mushahari and Muraul blocks were selected randomly for the study. Altogether 120 litchi grower farmers which were classified in to small, medium and large farmers, in these 40, 40 and 40 respondents were sampled, respectively. Cost concepts and farm profitability measures were used to analyse the primary data and compound growth rate and export performance measures the secondary data. The study reveals that the growth rates in area, production and productivity is positive and found 2.76,3.82 and 0.98, per cent, respectively in India while in Bihar it is recorded $1.19,3.02$ and 1.75 per cent and negative rate $-0.19,-2.07$ and -2.03 per cent, respectively in Muzaffarpur. The sample average for total cost of cultivation was 42730.86, gross return was 178267.55 and per hectare net profit at total cost was 135536.69.The growth rate analysis indicate that the export of litchi from muzaffarpur and from India increased by -1.64 and 6.34 per cent per annum during the period of 2001-02 to 2015-16. Per kg price realized for exported litchi during the above period was increased by 17.55 per cent per annum. The problems faced by growers about production were lack of technical know- how irregular fruit setting financial difficulties. The study, therefore, suggest that the litchi growers should be educated to use the recommended FYM and fertilizer application, which will help to increase the per cent level and litchi of production.

KEY WORDS : Litchi, Cost, Gross return, Net profit, Benefit growth rate instability, Benefit cost analysis

How To Cite This PAPER : Kumar, Janmejay, Kumar, Dinesh and Kumari, Nikky (2018). Economic analysis of production and export performance of litchi in Muzaffarpur district of Bihar. Res. J. Agric. Eco. \& Stat., 9 (2) : 325-330, DOI : 10.15740/HAS/IRJAES/9.2/325-330. Copyright@ 2018: Hind Agri-Horticultural Society. 